\title{
A Study of The Radionuclides of The Petroleum Waste \\ In Dora and Bijie Refineries Using (Hpge) Detector
}

\author{
Essam Mohammed Rasheed \\ Department of physics, College of Science, Al-Nahrain University
}

\section{Abstract:}

The aim of this study is to detect the radionuclides (Bi-214,Ra-226) radioactivity of radionuclides and belong to the U-238 series, three measure the specific activities and radionuclides (TI-208, $\mathrm{Bi}-212, \mathrm{~Pb}$ the uranium concentration in (19) samples of crude oil and oil waste were brought from two oil locations Dora refinery, Bijie refinery.

The measurements in this study were done by using two techniques:

1- Gamma rays spectroscopy system was used to measure the specific activity for radionuclides. This system is consist of high purity of germanium detector (HPGe) with personal computer as multi channel analyzer (MCA) that computerized to plot the radioactive spectrum and compute the specific activities of the radionuclides. There are seven radionuclides are detected:

(Bi-214, Ra-226, TI-208, Bi-212, $\mathrm{Pb}-212, \mathrm{~K}-40$, and Cs-137), these radionuclides included; two

212) belong to Th-232series, one natural radionuclide (K-40), and one artificial radionuclide (Cs-137).

For Dora refinery samples, the averages of specific activities of (Bi214, Ra-226) were $(7.79,16.08)$ $\mathrm{Bq} / \mathrm{kg}$ respectively, the averages of specific activities of (TI-208, Bi-212, $\mathrm{Pb}-212)$ were $(7.95,4.05,5.75) \mathrm{Bq} / \mathrm{kg}$ , the average of specific activities of (Cs-137) was (0.64) Bq/kg, the average of specific activities of (K40) was (99.3) Bq/kg.

For Bijie refinery samples, the average of specific activities of (Bi214) was (0.39) Bq/kg, the averages specific activities of (Bi-212, $\mathrm{Pb}$ 212) were $(0.02,0.01) \mathrm{Bq} / \mathrm{kg}$, the average of specific activities of (K40) was (2.28) $\mathrm{Bq} / \mathrm{kg}$, and three 
radionuclides (Ra-226, TI-208, and Cs-137) were not appeared in Bijie samples.

2- solid state nuclear track detectors technique (SSNTDs), the uranium concentration determined by using CR-39 track detector and fission fragment track technique, the nuclear reaction used as source of uranium fission fragment is U-235 (n-f) obtained by the bombardment of U235with thermal neutrons emitted from (Am-Be) neutron source with flux $(5000 \mathrm{n} / \mathrm{cm} 2 . \mathrm{s})$ for seven days, the concentration were calculated by comparison with the standard samples. The uranium concentration in Dora refinery samples were ranged between (0.95-3.34) ppm with average (2.03) ppm for solid samples and (1.25) ppm for liquid samples. The uranium concentration in Bijie refinery samples were ranged from $(0.42-1.46) \mathrm{ppm}$ with average (0.55) $\mathrm{ppm}$ in the solid samples and (1.24) ppm in the liquid samples, these results are agreement with the permissible limit from
IAEA, the permissible limit is $(1 \mathrm{mSv} / \mathrm{y})$ for the public.

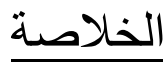

الهدف من هذا البحث هو الكثف عن النويدات المشعة وحساب الفعالية الإشعاعية النوعية وقياس نر اكيز اليورانيوم لتسعة عشر نموذجا من المخلفات النفطية الصلبة والسائلة والتي تم أخذها من موقعين نفطيين هما : مصفى الدورة و مصفى بيجي .

تم قياس تركيز اليورانيوم في هذا البحث

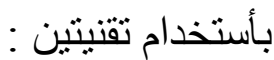

1- منظومة مطبافية أثنعة كاما لحساب الفعالية الإشعاعية النو عية للنويدات المشعة . وهذه المنظومة حديثة جدا ومصنعة من قبل شركة Canberra سنة /2008 مرتبطة مع كاثف الجرمانيوم عالي النقاوة (HPGe) متصل مع حاسوب يحتوي محلل طيفي متعدد القنو ات(MCA) مبرمج لرسم الطيف الإشعاعي وحساب الفعالية النوعية الإشعاعية للنويدات المشعة. حيث تم الكثف عن سبع نويدات مشعة

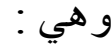

(Bi-214, Ra-226, TI-208， Bi-212, هذه النويداتPb-212，K-40，Cs-137)

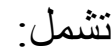
النويدتين (Bi-214, Ra-226) و اللتان تعودان إلى سلسلة تحلل U-238 - e أما النويدات الثلاثة ( Ac-228, Bi-212) فتعود الى سلسلة تحلل Pb-212 Th-232 
ونويدة طبيعية واحدة هي (K-40) , ونويدة صناعية واحدة هي (Cs-137) . أما بالنسبة الى نماذج مصفى الدورة فقد تم حساب الفعالية الإشعاعية النوعية وقد كان معدل الفعالية الإشعاعية النوعية للنويدتين (Bi-) 214, Ra-226 على التو الي (11.69, 24.13 , Bq/kg أما معدل الفعالية الإشعاعية النوعية للنويدات الثلاثة ( TI-208, Bi-212, Pb) 212 فكانت على التو الي 11.93,6.08,8.63 Bq/kg), أما معدل الفعالية الإشعاعية النوعية ) Bq/kg كان اللنويدة الصناعية (Bs-137) 0.97 ), أن معدل الفعالية الإشعاعية النوعية النويدة الطبيعية (K-40) كان Bq/kg ( 99.3 ) بالنسبة إلى نماذج مصفى بيجي فقد تم حساب Bi- معدل الفعالية الإشعاعية للنويدة 214 وكان Bq/kg (0.69)، أما بالنسبة للنويدتنين فقد كان معدل الفعالية (Bi-212,Pb-212) الإشعاعية النوعية Bq/kg (0.2,0.1 ) على التو الي , أما النويدة الطبيعية (K-40) فقد كان معدل الفعالية الإشعاعية النوعية Bq/kg (4.0) أما النويدات (Ra-226, TI-208,Cs-137) فلم تسجل أي فعالية أشعاعية.

\section{Introduction:}

The oil extraction and production industry generates several types of solid and liquid waste, scales, sludge, and water. There are typical residues can be found in such facilities and that can be contaminated with Naturally Occurring Radioactive Material (NORM). As a result of oil processing, the natural radionuclides can be concentrated in such residues, so the forming called Technologically Enhanced Naturally Occurring Radioactive Material (TENORM)[1].

Most of the radionuclides that appear in oil and gas stream belong to the U-238 and Th-232 natural series, and $\mathrm{K}-40$. Emphasis was given to the quantification of Ra-226, K-40 since these radionuclides are responsible for most of the external exposure in such facilities [2].

\section{Collection of samples:}

\section{After collecting the samples}

from many places with different times from the oil locations, the samples were stored for one month at normal laboratory conditions. This time is necessary to get a radiological equilibrating to the samples, before counting the concentration of natural radioactive material for each sample. 


\section{Samples of Dora refinery:}

Twelve samples were taken from many places inside the refinery shown in Table (1).

Table (1): The location of all samples inside the refinery

\begin{tabular}{|c|c|c|l|}
\hline $\begin{array}{c}\text { Sample } \\
\text { code }\end{array}$ & \multicolumn{1}{|c|}{ Date } & \multicolumn{1}{|c|}{ State-type } & Location of samples \\
\hline D1 & $2 / 6 / 2009$ & solid-sludge & $\begin{array}{l}\text { The oil waste from operated units } \\
\text { (Al-Sudanya) }\end{array}$ \\
\hline D2 & $2 / 6 / 2009$ & solid-scale & The oil waste from (heavy products) \\
\hline D3 & $2 / 6 / 2009$ & solid-sludge & The oil waste from (light products) \\
\hline D4 & $2 / 6 / 2009$ & solid-sludge & The oil waste around pit abandonment \\
\hline D5 & $2 / 6 / 2009$ & solid-sludge & The oil waste from (Hi-tech) \\
\hline D6 & $2 / 8 / 2009$ & solid-brines & The oil waste from beside of furnace \\
\hline D7 & $2 / 8 / 2009$ & solid-sludge & The depleting area of crude oil \\
\hline D8 & $9 / 8 / 2009$ & solid-sediment & Refining dep. down of furnace \\
\hline D9 & $9 / 8 / 2009$ & liquid-scale & The reached crude oil from Kirkuk \\
\hline D10 & $9 / 8 / 2009$ & liquid-scale & The reached crude oil from al-Basrah \\
\hline D11 & $9 / 8 / 2009$ & liquid-scale & The oil waste from (pit abandonment) \\
\hline D12 & $9 / 8 / 2009$ & liquid-scale & Reduce crude oil (RC) \\
\hline
\end{tabular}

\section{Samples of Bijie refinery :}

Seven samples were taken from many places inside the refinery shown in Table (2).

Table (2): The location of samples inside the refinery.

\begin{tabular}{|c|c|l|}
\hline sample code & state-type & \multicolumn{1}{|c|}{ location of samples } \\
\hline $\mathrm{J}_{1}$ & solid- sludge & The vacuum residue produces from RC \\
\hline $\mathrm{J}_{2}$ & solid-scale & The extract from heavy metal from RC \\
\hline $\mathrm{J}_{3}$ & solid-scale & The foam wax heavy metal from RC \\
\hline $\mathrm{J}_{4}$ & solid -sludge & The oil waste from storage tank \\
\hline $\mathrm{J}_{5}$ & solid -scale & Asphalt \\
\hline $\mathrm{J}_{6}$ & liquid-scale & Crude oil \\
\hline $\mathrm{J}_{7}$ & liquid-scale & RC \\
\hline
\end{tabular}




\section{Gamma-ray spectrometry (HPGe)}

\section{detector:}

Gamma spectrometry is a sensitive method of analysis that can yield analytical data for several different radionuclides in a single sample analysis [3]. Gamma-ray emission from a radionuclide usually proceeded by the particles emissions from radioactive beta decay (either $\beta^{-}$or $\left.\beta^{+}\right)$, and sometimes by alpha decay. The decay leaves the nucleus in either a ground or excited state. If the nucleus is in an excited state, the decay to ground state typically is achieved by gamma emission; nucleus may have many different energy levels through which it must pass before attaining a ground state configuration[4].

The general specification of the system is shown in Table (3).

Table (3): General specifications of (HPGe) detector.

\begin{tabular}{|c|c|}
\hline (HPGe) detector & The specifications \\
\hline Type of detector & Semi conductor, Ge \\
\hline Volume of crystal & $(3 \times 3)$ inch \\
\hline Gas used & liquid nitrogen at $77 \mathrm{~K}$ \\
\hline Operating voltage & $(-2500) \mathrm{V}$ d.c \\
\hline No .of channel & $(4096) \mathrm{ch}$ \\
\hline FWHM for (Co-60) & $(1.33) \mathrm{MeV}$ \\
\hline Relative efficiency & $30 \%$ \\
\hline Counting time for each sample & $(3600) \mathrm{sec}$ \\
\hline Resolution & $(2) \mathrm{KeV}$ \\
\hline Diameter & $(59.5) \mathrm{mm}$ \\
\hline Length & $(58.5) \mathrm{mm}$ \\
\hline Distance from the window & $(5) \mathrm{mm}$ \\
\hline Detector model & $\mathrm{GC} 3020$ \\
\hline Cryostat model & $7500 \mathrm{SL}$ \\
\hline
\end{tabular}




\section{Experimental details:}

- Oil waste and crude oil samples that had taken from the refineries are stored in the laboratory for one month to get a radiological equilibrating.

- One kg was taken from each solid sample and one liter was taken from each liquid sample using sensitive balance.

-Each sample was putting in the standard marinelli beaker, then tests for (3600) sec using (HPGe) detector.

\section{Results:}

- Samples of Dora refinery: Twelve samples had tested to measure the specific activities for the radionuclides shown in Table (4)

Table (4): The specific activities of the samples

\begin{tabular}{|c|c|c|c|c|c|c|c|}
\hline $\begin{array}{c}\text { Sample } \\
\text { code }\end{array}$ & $\begin{array}{c}\text { Bi-214 } \\
\mathrm{Bq} / \mathrm{kg}, \\
\mathrm{Bq} / \mathrm{l}\end{array}$ & $\begin{array}{c}\text { Ra-226 } \\
\mathrm{Bq} / \mathrm{kg}, \\
\mathrm{Bq} / 1\end{array}$ & $\begin{array}{c}\mathrm{Ac}-228 \\
\mathrm{~Bq} / \mathrm{kg}, \\
\mathrm{Bq} / 1\end{array}$ & $\begin{array}{c}\mathrm{Bi}-212 \\
\mathrm{~Bq} / \mathrm{kg}, \\
\mathrm{Bq} / \mathrm{l}\end{array}$ & $\begin{array}{c}\mathrm{Pb}-212 \\
\mathrm{~Bq} / \mathrm{kg}, \\
\mathrm{Bq} / 1\end{array}$ & $\begin{array}{c}\mathrm{K}-40 \\
\mathrm{~Bq} / \mathrm{kg}, \\
\mathrm{Bq} / 1\end{array}$ & $\begin{array}{c}\text { Cs-137 } \\
\mathrm{Bq} / \mathrm{kg}, \\
\mathrm{Bq} / 1\end{array}$ \\
\hline $\mathrm{D}_{1}$ & 6.61 & 12.60 & 7.34 & 3.34 & 5.52 & 117.86 & B.D.L \\
\hline $\mathrm{D}_{2}$ & 6.92 & 20.31 & 7.12 & 2.22 & 5.81 & 107.56 & 5.20 \\
\hline $\mathrm{D}_{3}$ & 8.41 & 4.11 & 9.91 & 5.61 & 8.32 & 178.9 & 0.70 \\
\hline $\mathrm{D}_{4}$ & 8.52 & 18.6 & 10.00 & 6.92 & 7.93 & 180.66 & B.D.L \\
\hline $\mathrm{D}_{5}$ & 6.22 & 14.10 & 7.62 & 4.94 & 5.32 & 140.62 & 0.75 \\
\hline $\mathrm{D}_{6}$ & 8.95 & 29.81 & 11.01 & 6.12 & 6.88 & 184.91 & 0.53 \\
\hline $\mathrm{D}_{7}$ & 8.83 & 14.54 & 10.13 & 6.66 & 6.74 & 189.31 & 0.32 \\
\hline $\mathrm{D}_{8}$ & 39.07 & 79.03 & 32.31 & 18.62 & 22.53 & 76.12 & 0.31 \\
\hline $\mathrm{D}_{9}$ & B.D.L & B.D.L & B.D.L & B.D.L & B.D.L & 5.24 & B.D.L \\
\hline $\mathrm{D}_{10}$ & B.D.L & B.D.L & B.D.L & B.D.L & B.D.L & 6.74 & B.D.L \\
\hline $\mathrm{D}_{11}$ & B.D.L & B.D.L & B.D.L & B.D.L & B.D.L & 2.23 & B.D.L \\
\hline $\mathrm{D}_{12}$ & B.D.L & B.D.L & B.D.L & B.D.L & B.D.L & 1.82 & B.D.L \\
\hline Average & $11.69 \pm 1.2$ & $24.13 \pm 1.7$ & $11.93 \pm 1.2$ & $6.08 \pm 0.8$ & $8.63 \pm 1.0$ & $99.3 \pm 2.8$ & $0.97 \pm 0.3$ \\
\hline
\end{tabular}

B.D.L below detection limit 


\section{- Samples of Bijie refinery :}

Seven samples were tested to measure the specific activities for the radionuclides shown in Table (5).

Table (5): The specific activities of samples

\begin{tabular}{|c|c|c|c|c|c|c|c|}
\hline $\begin{array}{l}\text { Sample } \\
\text { code }\end{array}$ & $\begin{array}{l}\mathrm{Bi}-214 \\
\mathrm{~Bq} / \mathrm{kg}, \\
\mathrm{Bq} / 1\end{array}$ & $\begin{array}{l}\mathrm{Ra}-226 \\
\mathrm{~Bq} / \mathrm{kg} \\
\mathrm{Bq} / 1\end{array}$ & $\begin{array}{l}\mathrm{Ac}-228 \\
\mathrm{~Bq} / \mathrm{kg}, \\
\mathrm{Bq} / \mathrm{l}\end{array}$ & $\begin{array}{l}\mathrm{Bi}-212 \\
\mathrm{~Bq} / \mathrm{kg} \\
\mathrm{Bq} / 1\end{array}$ & $\begin{array}{l}\mathrm{Pb}-212 \\
\mathrm{~Bq} / \mathrm{kg}, \\
\mathrm{Bq} / 1\end{array}$ & $\begin{array}{l}\mathrm{K}-40 \\
\mathrm{~Bq} / \mathrm{kg} \\
\mathrm{Bq} / \mathrm{l}\end{array}$ & $\begin{array}{l}\mathrm{Cs}-137 \\
\mathrm{~Bq} / \mathrm{kg}, \\
\mathrm{Bq} / \mathrm{l}\end{array}$ \\
\hline $\mathrm{J}_{1}$ & B.D.L & B.D.L & B.D.L & B.D.L & B.D.L & B.D.L & B.D.L \\
\hline $\mathrm{J}_{2}$ & B.D.L & B.D.L & B.D.L & B.D.L & B.D.L & B.D.L & B.D.L \\
\hline $\mathrm{J}_{3}$ & 1.90 & B.D.L & B.D.L & B.D.L & B.D.L & 5.73 & B.D.L \\
\hline $\mathrm{J}_{4}$ & 0.15 & B.D.L & B.D.L & 0.20 & B.D.L & 2.54 & B.D.L \\
\hline $\mathrm{J}_{5}$ & 0.21 & B.D.L & B.D.L & B.D.L & 0.10 & 3.12 & B.D.L \\
\hline $\mathrm{J}_{6}$ & 0.53 & B.D.L & B.D.L & B.D.L & B.D.L & 4.64 & B.D.L \\
\hline $\mathrm{J}_{7}$ & B.D.L & B.D.L & B.D.L & B.D.L & B.D.L & B.D.L & B.D.L \\
\hline Average & $0.7 \pm 0.4$ & B.D.L & B.D.L & 0.2 & 0.1 & 4.0 & B.D.L \\
\hline
\end{tabular}

\section{Discussion:}

There are seven

radionuclides are detected from our samples:

(Bi-214, Ra-226, Ac-228, Bi-212, pb-212, K-40, and Cs-137), these radionuclides included; two radionuclides $(\mathrm{Bi}-214, \quad \mathrm{Ra}-226)$ belong to the U-238 series, three radionuclides (Ac-228, Bi-212, pb212) belong to Th-232 series, one natural radionuclide (K-40), and one artificial radionuclide (Cs-137).

For Dora refinery samples, the average specific activities of (Bi214, Ra-226) were $(11.69,24.13)$ $\mathrm{Bq} / \mathrm{kg}$ respectively, the average specific activities of (Ac-228, Bi$212, \mathrm{pb}-212)$ were $(11.93,6.08,8.63)$ $\mathrm{Bq} / \mathrm{kg}$, the average pecific activities of artificial radionuclide (Cs-137) was (0.97) $\mathrm{Bq} / \mathrm{kg}$, the average of specific activities of natural radionuclide (K-40) was (99.3) Bq/kg.

For Bijie refinery samples, the average of specific activities of (Bi214) was (0.69) Bq/kg, the average specific activities of (Bi-212, pb212) were $(0.2,0.1) \mathrm{Bq} / \mathrm{kg}$, the average specific activities of natural radionuclide (K-40) was (4.0) Bq/kg. 
There are three radionuclides (Ra226, Ac-228, and Cs-137) were not appeared in Bijie samples.

Workers and people that live in oil locations and refineries most likely to be exposed to this source of radiation from oil waste, but production sites can also pose a potential hazard to members of the public. This may be present in produced water, drilling mud, or can concentrate in pipes, storage tanks, or other extraction equipment. The contamination may be present in mineral scale, sledges, slimes, or evaporation ponds or pits. The radiation comes from (NORM) in the underground rock and sediment. When companies drill for gas or oil, the produced fluids, including water, may contain radionuclides, primarily radium-226, radium-228, and radon. The radon gas may be released to the atmosphere, while the produced water and mud containing radium are placed in ponds or pits for evaporation, re-use, or recovery. 


\section{References:}

1. EPA, Technical report on "Technologically enhanced naturally Occurring radioactive material ", in south western copper belt of Arizona,USA , p 23-33 ,October,(1999).

2. International Atomic Energy Agency, Al- Masri, and Suman .H, "NORM Waste in Oil and Gas Industry" The Syrian Experience "AECS_CN-87/78, Malta, p 67-90, ( 2001).

3. Pataki George $E$, and Cahill John .p," An Investigation of Naturally Occurring Radioactive Material (NORM) in oil and Gas wells" New York state, p 66,98-110,( 2002).

4. International Atomic Energy Agency Lindberg M, and Eriksson A. "Treatment of NORM Contaminated Scrap from the oil and Gas Industry " Studsvik Radwast AB Nykoping, Sweden, IAEA-CN87/76, Malta, p 68,98, ( 2003). 